\title{
CHINESE PATHWAYS TO PEACEBUILDING: FROM HISTORICAL LEGACIES TO CONTEMPORARY PRACTICES
}

\author{
Xinyu Yuan ${ }^{*}$ \\ Graduate Institute of International and Development Studies, Geneva ${ }^{\text {** }}$
}

DOI: 10.20542/2307-1494-2020-1-26-45

\begin{abstract}
Since the early 2000s, China has become increasingly active in conflict management and postconflict reconstruction - especially in South-East Asia and Sub-Saharan Africa, and, more recently, along the route of the Belt and Road Initiative. Its engagement in postconflict settings ranges from preventive diplomacy, conflict mediation, and development assistance to business-oriented economic construction. A rough consensus has formed that a peacebuilding paradigm "with Chinese characteristics", termed "developmental peace" by Chinese scholars, is in the making and is gaining influence over war-torn societies. While there is an emerging body of theoretical and empirical literature to identify, describe, and analyze the substances, mechanisms, and implications of Chinese developmental peace, little attention has been paid to its historical origins and philosophical basis. This article posits that it is through selective reinforcement of certain historical memories and elaborate interpretation of national experience of development (or decay) that China"s contemporary narrative and practices around peace and security emerge, persist, and evolve. In order to further understanding of China"s norms and practices in the areas of conflict management and peacebuilding, this article offers a critical historical review of China"s encounter with the international system.
\end{abstract}

Keywords China, developmental peace, peacebuilding, international system, sovereignty, non-interference, socio-economic development, historical legacies

\section{Название Подходы Китая к восстановлению мира: от исторического опыта статьи к современным практикам}

Аннотация С начала 2000-х годов Китай все активнее участвует в регулировании конфрликтов и постконфликтном восстановлении, особенно в Юго-Восточной Азии и Африке южнее Сахары, а с недавнего времени - в районах вдоль прохождения маршрутов инициативы «Один пояс, один путь». Роль КНР в постконфликтных зонах варьируется от превентивной дипломатии, посреднических усилий и помощи по развитию до коммерческих программ экономического восстановления. Среди экспертов сложился определенный консенсус относительно того, что идет формирование особой модели миростроительства «с китайским лицом» (или, согласно китайским специалистам, модели «мирного развития»), влияние которой в постконфрликтных обществах растет. Хотя объем теоретических и эмпирических исследований, посвященных описанию и анализу сущностных

\footnotetext{
* Xinyu Yuan is Doctoral Researcher at the Centre on Conflict, Development and Peacebuilding, Graduate Institute of International and Development Studies, Geneva (Switzerland).

Ксинью Юань - исследователь Цента по конфликтам, развитию и миростроительству Института международных исследований и развития, Женева (Швейцария).

** This article has been prepared as a part of a collaborative international research project "Coherence or Contestation: Chinese, Japanese and Russian Approaches to The Transformation of Peacebuilding Practices" hosted by the Centre on Conflict, Development and Peacebuilding of the Graduate Institute of International and Development Studies in Geneva, Switzerland.
} 
характеристик, механизмов и значения китайской модели мирного развития растет, ее историческим истокам и философской базе уделяется меньше внимания. В статье утверждается, что современный дискурс и практика КНР в сфрере мира и безопасности формируются и развиваются путем избирательного акцентирования исторической памяти и тщательно продуманной интерпретации китайского опыта национального развития (или упадка). Для углубления понимания китайских норм и практик в области регулирования конфликтов и миростроительства в статье предложен критический исторический обзор взаимодействия КНР с международной системой.

Ключевые Китай, теория мирного развития, миростроительство, международная систеслова

ма, суверенитет, невмешательство, социально-экономическое развитие, исторический опыт

\section{Introduction}

Since the early 2000s, China has become increasingly active in conflict management and postconflict reconstruction, especially in South-East Asia and SubSaharan Africa, and, more recently, along the route of the Belt and Road Initiative (BRI). For example, overall, by late 2019, the Chinese government had deployed 39000 personnel to UN peacekeeping operations (UNPKOs). ${ }^{1}$ At the time of writing, there were still 2544 Chinese peacekeepers serving in eight of the thirteen ongoing UNPKOs, including the "big five" UN missions in Mali, South Sudan, the Democratic Republic of the Congo, the Central African Republic, and Sudan (Darfur). While China did not join the UN Special Committee on Peacekeeping Operations until 1988, it became a major champion of the UN peacekeeping over the last three decades. Chinese peacekeeping forces deployed in UN missions far outnumber those of other permanent members of the UN Security Council (UNSC). ${ }^{2}$ China"s financial contribution to the UN peacekeeping budget has been steadily climbing to become second only to that of the USA and has accounted for $15.21 \%$ of the regular budget in $2019-2021$. $^{3}$ Apart from UNPKOs, China has also been increasingly involved in preventive diplomacy, conflict mediation, development assistance, and business-oriented economic construction of conflictaffected and fragile states.

A rough consensus has thus formed that a peacebuilding paradigm "with Chinese characteristics" is in the making and is gaining influence over war-torn societies. ${ }^{4}$ In 2011 , Zhao Lei, professor at the Central Party School of the Communist Party of China, clearly highlighted the primary focus on development in China"s global peace engagement, ${ }^{5}$ an observation that also appeared in non-Chinese research publications such as the 2012 report by "Saferworld". ${ }^{6}$ In 2015, South African researcher Steven Kuo explicitly referred to "Chinese peace" in analyzing China"s norm-making role in Africa"s postconflict security architecture. ${ }^{7}$ In the same year, Paul Gwaza from the Institute for Peace and Conflict Resolution in Nigeria first used the term "developmental peace" to describe Chinese peacebuilding model in his report. ${ }^{8}$ However, the term only started to capture academic attention when it appeared in the 2017 publication of He Yin, a scholar at the Chinese UN Peacekeeping Police Training Center and himself a peacekeeper who served in the UN Transitional Administration in East Timor (UNTAET) in 2001-2002. ${ }^{9}$ Another Chinese researcher of Sino-African relations, Wang Xuejun, then adopted the term in an edited book on China"s peace and security policies towards Africa. ${ }^{10}$ The rise of "developmental peace" was echoed by over 20 Chinese researchers in interviews conducted by the 
author in the summer of 2019. Coming from a variety of fields, including development assistance, security studies, the China-UN context, Chinese policies on regional hotspots etc., the respondents generally agreed that developmental peace provides a more or less accurate description of China"s current peacebuilding practices, but made some reservations about the existence of a coherent Chinese model.

Although consensual terminology is still in the making, this article goes for "developmental peace" for its analytic utility: the term echoes Chinese official discourse on "peace through development, equality, and cooperation" that President-to-be Xi Jinjing systematically employed at the First World Peace Forum held by Tsing Hua University in Beijing in July 2012. ${ }^{11}$ This article also builds on He Yin"s depiction of developmental peace as entailing the following interrelated arguments. First and foremost, conflicts are directly related to a lack of socio-economic development, basic social goods and poverty. Resurgent conflicts also reflect the hegemonic and insular essence of the Western-dominated world order $^{12}$ that perpetuates, reinforces, and deepens insecurity of weak and conflict-ridden states in the international system. Based on this worldview, China envisions that: (1) peace is contingent on sustained socioeconomic development, especially infrastructural networks that promote growth and connectivity; (2) sustainable growth requires a competent and strong state authority that can act as a central coordinator of postconflict reconstruction; and (3) norms of noninterference and classical state sovereignty need to be pursued unequivocally and resolutely to maintain the domestic, regional, and international stability that forms the basis for external peace efforts. ${ }^{13}$ The norms of developmental peace, including prioritizing socio-economic concerns over political reconfiguration, "good government" over "good governance," and non-interference (as opposed to conditional sovereignty), have been reflected in a range of practices advanced by China. They include China"s contribution to consent-based UNPKOs, non-contingent development assistance that typically aims to boost depleted state capacity (e. g. through infrastructure projects), and expanding business-oriented partnerships designed to spur sustainable growth, mutual benefits, and "common security". 14

International Relations scholars both within and outside China have contributed to an emerging body of theoretical and empirical literature to identify, describe, and analyze the substance, mechanisms, and implications of Chinese developmental peace, ${ }^{15}$ sometimes without making a reference to the term itself. Surprisingly little attention, however, has been paid to the historical origins and philosophical basis of China"s emerging approach to conflict and peace issues. Research is critically limited when it comes to why China advocates an approach that mainly aims at taming conflicts through socio-economic development, construction of an effective, stable, and hierarchical state, and transformation of the international system as elaborated above. While several Western scholars and pundits maintain that the Chinese peace engagement strategy stems from its "authoritarian" and "autocratic" ideology, the linkage between regime characteristics and developmental peace is not straightforward ${ }^{16}$ and has rarely been examined so far. Counterintuitively, the core of the developmental peace rests on Westphalian sovereignty and market-oriented economic growth that are in fact products of the "liberal world" and the antithesis of the (original) communist doctrine of anti-sovereignty (state sovereignty as a bourgeois conspiracy to divide and conquer the world) and anti-market (marketization as a precedent and embodiment of the capitalistic evil). That being said, more refined analysis is needed on where China's approach to peacebuilding comes from.

This article posits that a critical review of China"s historical experience of its encounter with the international system can help advance understanding of 
contemporary China"s norms and practices in the terrain of conflict management and peacebuilding. All history is contemporary history - and yet, it is the contemporary interpretation of historical experiences that molds how we think and act at present. It is through selective reinforcement of certain historical memories and elaborate interpretation of national development (or decay) experience that the contemporary discourse and practices of China around peace and security emerge, persist, and evolve. To a large extent, the so-called developmental peace is embedded in China"s bitter historical experiences of surviving and striving in a hostile international system dominated by imperial and hegemonic powers, amidst "a hundred years" national humiliation" and the Cold War. The Chinese overwhelmingly believe that the "long peace" that had defined the regional order in East Asia for centuries before the advent of imperialism stemmed from the peaceful nature of Chinese power and shared norms of harmony, reciprocity, and openness in the region. However, in the mid-nineteenth century, China was forcibly incorporated into the Westphalian system through unequal treaties and imperial land-grabs that exposed the country to the idea of national sovereignty while depriving it of substantive sovereign rights. The highly contrastive historical experiences of the Chinese civilization have fueled both a sense of moral superiority vis-à-vis Western powers and a feeling of being a victim of Western imperialism. Therefore, following the establishment of the People's Republic of China (PRC), the Chinese government was dedicated to strengthening national security in the West-dominated anarchical international system based on its interpretation of classic sovereignty norms, such as independent diplomacy, sovereign integrity, and racial equality. Meanwhile, transforming the West-centric hegemonic order became a focal point of the Chinese way to address the "systematic risk" for global peace, as a free, just and democratic international order was conceived to be a precondition for sustainable peace. $^{17}$

While the focus on sovereignty informs the Chinese notion of the boundaries and modalities of external intervention in peacebuilding processes, a deep belief in the intrinsic link between underdevelopment and insecurity drives China to embrace a development-focused agenda. ${ }^{18}$ Striving for peace and security is tied to the promotion of development. While the indispensable role of development to achieve security (and vice versa) has been increasingly recognized by liberal peacebuilding actors since the early 2000 s, ${ }^{19}$ what makes China an "outlier" of the "mainstream agenda" is its approach based on the primacy of development plus distribution of economic resources. Developmental peace prioritizes capacity-building of state actors (agencies) of a host country ${ }^{20}$ and programs that help unlock its economic potential. Empirically, this approach routinely leads to a business-oriented and state-led peacebuilding model. While this model is often criticized for "authoritarian diffusion", ${ }^{21}$ it actually goes beyond an "authoritarianism-versus-democracy" dichotomy that plagues the Euro-Atlantic intellectual space. In fact, a "development first" approach is taken as "common sense" by states beyond the circle of Western powers and has been endorsed by some nonWestern democracies as well, including Japan, ${ }^{22}$ India, South Korea, Brazil, Indonesia, and South Africa, among others. ${ }^{23}$ The fact that the central focus on development is well received across regime types beyond the Euro-Atlantic community points at the relevance of their shared historical experience of poverty, civil wars, foreign invasion, and loss of status under conditions of weak states and backward economies.

Informed by this historically-sensitive approach, the remainder of this article unpacks why and how the recent approach of developmental peace came into being in the context of the China"s reforms and opening up since 1978. It will do so by analyzing the three pillars of development peace, namely, the inclusive international system as a 
precondition for peace (section II), Westphalian sovereignty as a basis of peace (section III), and development as a pathway towards peace (section IV). The final section V synthesizes these analytical insights. The article"s source base includes key selected historical documents, Chinese leaders" statements, and a review of secondary literature by prominent Chinese scholars on IR and history. In addition, the analysis benefits from interviews with Chinese scholars and practitioners conducted in Beijing and Shanghai in 2019 that allow the author to approach the highly historical and contextual "Chinese pathways" from an internal perspective.

\section{Inclusive international system as the precondition for peace}

The Chinese understanding of peace and security rests on a supposedly close association between external environment and internal stability. ${ }^{24}$ Traditional political wisdom in China suggests that the longevity and vitality of a lower-level unit always depends on an upper-level order, which constitutes its operating context. ${ }^{25}$ For instance, family stability is contingent on a well-ordered state, and national security is conditional on a peaceful and enabling international system. Drawing on the widely held historical (albeit Sinocentric) perception of the "Long Peace" in East Asia before Western penetration, ${ }^{26}$ that stands in stark contrast to the recurring wars and violence sweeping over China and the region after the arrival of the Western forces in the mid-19 ${ }^{\text {th }}$ century, the Chinese government habitually turns to elements of China"s political culture to advocate for a new international order that allegedly would preserve and boost its constituent states. ${ }^{27}$ The history of pre-Western East Asia was remarkably peaceful, ${ }^{28}$ almost without major inter-state wars between the 14th and 19th century. ${ }^{29}$ From the Chinese perspective, this historical experience is rooted in shared anti-war cultural norm and inclusive institutional arrangements that underpinned the regional order, known as the Confucian Long Peace, for millennia. ${ }^{30}$ The effect of these cultural restraints on behavioral characteristics of Confucian states remains an issue of academic debate, ${ }^{31}$ and the Chinese military hegemony seemingly fits the theory of hegemonic peace fairly well. Nevertheless, realist explanations miss the point of why the relationship between the Chinese empire and Confucian states were evidently more peaceful relative to those with non-Confucian ones in the broader region, ${ }^{32}$ despite a shared hypothetical threat of the "Chinese hegemony". The war-reducing Confucian ideals and related institutional arrangements shared by East Asian states are believed to have played a significant role in building "legitimacy" on moral superiority and generating a sense of "we-ness" among "multi-ethnic population and vast territories". ${ }^{33}$ Contemporary China has cautiously avoided references to this essentially hierarchical system in its projection of a peaceful international image, nor does it aim to restore this historical order. However, the government continues to advance a worldview featuring cooperative inter-state relations and harmony of interests in contrast to the prevailing realist assumptions in International Relations based on an abstraction of its "peace-loving culture and political traditions." For instance, President Xi Jinping, in an address to neighboring Mongolia, asserted that "China is a peace-loving nation that values harmony. For over 5000 years of its civilization, China has unswervingly advocated and promoted the ideas of peace, amity and harmony [...] All these ideas have taken deep root in the heart of the Chinese people and shaped their characters and behaviors". 35

Western observers tend to dismiss such a narrative of China"s complex history, undoubtedly selective and reductionist, as merely a way to quell suspicions about China"s rise. However, as Daniel Bell noted, while this arbitrary judgment may be partly true, it does not tell the whole story. ${ }^{36}$ There is often a genuine belief in China"s 
peacefulness as a great power as opposed to the intrusive and militarized propensity of Western hegemony, ${ }^{37}$ since "acquiring overseas territories for population resettlement never occurred in Chinese history", ${ }^{38}$ while the West intervened in the region bringing over colonialism and imperialism during the so-called century of national humiliation that lasted from 1839 (the First Opium War) to 1949 (when the People"s Republic of China was founded).

In the aftermath of the arrival of Western military forces in the mid- $19^{\text {th }}$ century, protracted peace in East Asia was replaced by sweeping violence and human suffering. For China plunged into civil war, poverty, and chaos ${ }^{39}$ this was a bitter experience, involving the involuntary reconstruction of territory, self-identity, and national interests. Within a very short period, vassal states of the Chinese empire, such as Liuqiu (Lambai Island), Burma, Annam, and Laos, were encroached by the imperial West under the banner of "liberal blessings," accompanied by an array of treaties that "surrendered China"s sovereign rights under humiliating terms." ${ }^{40}$ This recent historical memory stands as an enduring reminder of the intrusive and hegemonic essence of the international system dominated by the West under the guise of emancipatory "liberal" discourses. An often-cited illustration is the Paris Peace conference of 1919-1920 where the Chinese demands to recover the German "leased" territory of Jiaozhou and abolish extraterritoriality privileges of the imperial West (plus Japan) within China were blocked, despite the conference"s self-proclaimed anti-war spirit and focus on self-determination and territorial integrity. ${ }^{41}$ Ironically, during the century of national humiliation, China was invaded and dismantled in the process of historical expansion of the Westphalian system, which (at least rhetorically) endorsed sovereignty, equality between states, and non-interference. As a result, a deep mistrust towards the West-dominated international system emerged and was reinforced by the continuous international struggle for power during the first three decades since the PRC"s birth, in the context of the Cold War.

Therefore, Communist China, upon its establishment in 1949, was compelled to transform the hegemonic and exclusive international system into the one based on principles of equality, justice, and anti-hegemony, ${ }^{42}$ initially through Socialist revolutions and later via more moderate reform efforts characterized by gradualism and a participatory approach. Chairman Mao Ze Dong and his comrades believed that genuine peace at home could not be achieved as long as imperialist and hegemonic Western powers dominate at the international level ${ }^{43}$ and autocratically rule the world in the name of liberal leadership. ${ }^{44}$ Chinese moral and material support to liberation movements in "the most oppressed countries" aimed at cultivating solidarity among the Third World countries $^{45}$ that leaders of the Chinese Communist Party (CCP) thought would form a solid anti-hegemonic force. While ideologically driven, China"s active support to national liberation / anticolonial movements, especially in Africa, ${ }^{46}$ was also deeply rooted in a particular understanding of Chinese history and culture in terms of its dual identity as a great peaceful power in history and a recent victim of Western imperialism. In Zhang Feng"s words, this dual historical experience fueled exceptionalism in China"s foreign policy ${ }^{47}$ based on a set of assumptions and convictions about the moral virtue of China vis-à-vis other major (Western) powers. The Communist government stressed that China shared with all the oppressed and weak countries their plight and aspirations for independence, justice, equality, and prosperity, ${ }^{48}$ on the grounds of their common collective experience of imperial order, a narrative constantly utilized to impair the prevalent intrusive tendency and power politics embedded in the existing international system. For instance, President Xi Jinping reiterated at different occasions that "the modern history of China is a humiliating and tragic record of miserable sufferings, and at the same time, it captures the epic struggle of the Chinese people to resist foreign 
aggression and realize national independence. Emerging from untold suffering, the Chinese people cherish the value of peace and will never want to see other nations go through the same pains it underwent in the past". 49

Constructing an ontological status of moral superiority both serves China"s strategic purposes ${ }^{50}$ and is consistent with the perceived historical experiences of "Confucian Peace" as opposed to hundred years of national humiliation and turbulence inflicted by the West. In the context of China"s "peaceful rise" since the early 2000s, the idea of reforming international institutions through constructive participation replaced revolutionary attempts to achieve the same goal of fabricating a "fair, free, and peaceful" system non-conducive to conflicts within and between states. The concept of a "harmonious world" proposed by President Hu Jintao magnifies China"s effort in this regard: it builds significantly on the Confucian ideals, ${ }^{51}$ but remains vague about concrete pathways to, and structures of, a new world order. He Yin, an advocate of China"s developmental peace, also highlights the need for transformation of the international system towards greater inclusiveness and sovereignty equality, ${ }^{52}$ which implies both power redistribution at the global decision-making bodies (towards a more adequate representation of states of the "Global South") and consolidation of the universal values such as equality, diversity, and justice. In short, through highlighting the historical experience of the "long peace" in the pre-Western time and of China as a victim of Western imperialism during the century of national humiliation, the notion of peace being contingent on the international system has been deeply engrained in Chinese policy thinking. Meanwhile, the belief that China commands a moral high ground ${ }^{53}$ as a result of this exceptional historical experience has impacted, if not determined, the nation"s constant efforts to transform a world order that it deems to be essentially hegemonic and exclusive, albeit to varying degrees and with means that have evolved over time.

\section{Westphalian sovereignty as the basis for peace}

The painful historical experience of state breakdown, territorial loss, and overwhelming human suffering inflicted by Western imperial interventions in the period of the hundred years of humiliation eventually translated into a strong impulse to pursue sovereign equality and integrity ${ }^{54}$ among not only political elites but also ordinary citizens of China. Upon the founding of Communist China in 1949, Chairman Mao set forth three grand strategies guiding the country"s foreign relations, namely "Starting anew" ("Lingqi Luzao"), "Putting the house in order before inviting guests" ("Dasao Ganjing Wuzi Zai Qingke"), and "Leaning to one side" ("Yi Bian Dao"). ${ }^{55}$ The first two principles aim at eliminating the residual influence of the West within China and establishing new diplomatic relations on an equal footing. ${ }^{56}$ In doing so, China started postwar peacebuilding at home, with low tolerance for foreign intervention or intrusion of any kind, including that of its military and political ally, the Soviet Union. ${ }^{57}$ Chinese communist leaders emphasized that all forms of cooperation between China and the Union of Soviet Socialist Republics (USSR) should be based on sovereign equality and non-interference in their respective domestic affairs, ${ }^{58}$ be it the construction of a long-wave military radio station on Hainan Island ${ }^{59}$ the establishment of a joint submarine fleet around Chinese ports, ${ }^{60}$ or the handling of border relations. ${ }^{61}$

In line with the spirit of state sovereignty, Premier Zhou Enlai and his Indian and Myanmar counterparts put forward the Five Principles of Peaceful Coexistence in June 1954. They include: (1) mutual respect for sovereignty and territorial integrity; (2) mutual non-aggression; (3) non-interference in each other's internal affairs; (4) equality and mutual benefit; and (5) peaceful coexistence. From the perspective of these three 
countries, building endurable peace in the postcolonial and post-imperial international order is a process inextricably bound to the consolidation of the Five Principles ${ }^{62}$ that are representative of Westphalian sovereignty. Driven by an understanding of sovereignty "in the most vehement terms", ${ }^{63}$ China showed remarkable vigilance at home in detecting and preventing potential erosion of sovereignty, an approach widely shared by most newly independent nation-states. ${ }^{64}$

Building on the unwavering primacy of sovereign prerogatives, contemporary China"s discourse and practices regarding conflicts and conflict management have generally been framed in line with the principle of non-interference, except in the period of radical Communism under Mao's charismatic leadership. For China of the past forty years of reform and opening up, the adherence to non-interference was meant to prevent any form of Western intervention related to controversial aspects of the Chinese policies ranging from religious issues, separatist movements, and China"s political and governance model to territorial disputes with neighboring countries. ${ }^{65}$ Therefore, before the grand strategy of "responsible power" gained prominence in China"s security policy, Beijing had already strongly opposed the idea of external interventions to restore or build peace. From the Chinese viewpoint, externally imposed operations were essentially at odds with state sovereignty of the host country, ${ }^{66}$ especially those operations that advanced maximalist goals under the banner of liberalization.

While the West criticized China"s hesitation to accept the notion of "sovereignty as responsibility", or "responsibility to protect" (R2P), in the aftermath of atrocities in the Balkans and Rwanda, as well as the 1999 NATO military intervention in Kosovo, it seemingly provoked the deeply-held concern of Chinese (and other non-Western countries) over sovereignty loss and the resulting turmoil, a lived experience of "violencein-the-name-of liberalism" ${ }^{\text {"67 }}$ shared by these latecomers to the Westphalian system. In this vein, China"s skeptical view of R2P is largely derived from its concern that the norm may be operationalized selectively and arbitrarily to justify powerful countries" interference in the domestic affairs of the weak. ${ }^{68}$ In other words, China"s opposition to intrusive "peace" operations stems from a historically informed notion of sovereignty as the basic weapon of self-defense for weak states in the Darwinian international order. ${ }^{69}$ Likewise, China does not dismiss the concept of human security per se, yet constantly links it to collective security and sovereign rights of a country. ${ }^{70}$

Some Western scholars suggest that China"s adherence to traditional understandings of sovereignty is rooted in the country"s "authoritarian" culture and serves to mobilize support for "antidemocratic" regimes in postconflict settings. ${ }^{71}$ However, this view ignores the fact that most non-Euro-Atlantic democracies, such as Brazil and India, uphold a stance on sovereignty similar to that held by China. Notably, even "democratic" Western allies in East Asia, such as Japan and South Korea, share China"s perspective on the primacy of state sovereignty. Sovereign equality and integrity, the Western constructs in the first place, have been internalized by China and other non-Western nations that historically were victims of the Western interventionism. For these nonWestern countries, the key to national security and societal stability is precisely to obtain fully acknowledged sovereignty in the world order dominated by the West. This partly explains the resonance China"s developmental peace has received across the world, ${ }^{72}$ particularly in Asia and Africa. This is not to argue that China is morally superior on sovereignty issues or driven solely by the imperative to "save the world" from the "imperial and militarist West." Rather, this section attempts to draw attention to the relevance of the lived historical experiences of non-Western countries, including China, which the "liberal mainstream" tends to ignore, instead overrating regime characteristics. In sum, China is rising in the domain of global peace and security not because its 
"illiberal" peace appeals to autocrats across the world, but, more likely, because the sovereignty-based developmental peace approach taps into their discomfort with the Western interventionism ${ }^{73}$ that the liberal peace is seen to imply.

\section{Development as the pathway to peace}

China"s developmental peace is critically informed by its own experience of overcoming domestic (postcolonial) conflicts through sustained economic growth and improved social well-being guided by strong state authority. In the deeply rooted statist culture of China, people identify the state with organizations and leadership: they measure the government"s legitimacy in terms of its effectiveness in securing a wellordered society and providing public goods. ${ }^{74}$ Citizens also expect the state to mobilize the nation on behalf of collective interests, even at the cost of individual rights, if necessary. ${ }^{75}$ Likewise, the legitimacy of the Communist regime rests not only upon its normative claims (the ideological pursuit in the context of Mao"s China), but no less on its performance in delivering collective goals and tangible benefits to the people. In particular, socio-economic security stands as the foremost priority. ${ }^{76}$ It is believed that if the state fails to improve the well-being of its people, popular uprisings driven by societal grievance will inevitably break out in response to failed governance. Hence, the durability of a state is contingent on its performance in improving livelihoods of its citizens (socalled performative legitimacy), especially those citizens who are severely repressed economically - for it is poverty that leaves them "nothing to lose" and thus makes them rebel against existing institutions.

Therefore, Communist China since its birth prioritized industrialization and agricultural reform, in order to achieve a major increase in national wealth and public welfare within a short time span. The development project known as the "Great Leap Forward" (1958-1962) aimed at "surpassing the UK within three years and catching up with the USA within five years" ("Sannian Chaoying, Wunian Ganmei"). ${ }^{77}$ The Chinese population"s general receptiveness to this ambitious goal reflected a nation-wide compulsion to rapidly transform the agrarian society into an industrialized economy, something that would stabilize and secure the new regime. Although the planned economy and radical tactics employed during Mao"s era proved to be a failure, with often devastating consequences, ${ }^{78}$ the supposed causal link between poverty and instability remained constant over the years and eventually spurred a strong streak of pragmatism in China"s strategy of peaceful rise since the early 2000s. Consequently, in the field of international peacebuilding, contemporary China also focuses on socio-economic engagement in conflict-affected states and emphasizes the role of infrastructure connectivity, poverty reduction, and trade and investment in forming a virtuous circle between security and development. ${ }^{79}$ Hence, underdevelopment is seen the crosshistorical and contextual root cause of insecurity, whereby peace-through-development is envisioned as a universal "recipe" for postconflict environments.

In particular, China"s foreign aid to conflict-affected states has brought to the fore infrastructure projects since the 1970s. Such projects were not only conceived as economic arteries but also as a key to consolidating state authority. In line with this approach, China provided USD 406 million for construction of the "Great Uhuru Railway" (TAZARA Railway), its flagship aid project, and USD 1.46 billion of interest-free loans for the railway"s operation. ${ }^{80}$ By linking the port of Dar es Salaam in east Tanzania with the town of Kapiri Mposhi in Zambia"s Central Province, TAZARA was expected to help reduce the deep economic dependence of Zambia on Rhodesia and South Africa. ${ }^{81}$ China proclaimed the railway to be a massive stride towards boosting the national 
economies of Tanzania and Zambia, while contributing to the security and liberation of these newly independent countries. ${ }^{82}$

Until today, infrastructure projects continue to be the focal point of ever-growing Chinese aid, with extensive official development assistance (ODA) combined with commercial investment in railway systems, agricultural facilities, and natural resource exploitation in least-developed countries that, from the perspective of China, are also most vulnerable to external and internal conflicts. The massive development project of the Belt and Road Initiative (BRI) constitutes the latest iteration of this approach. By the Second BRI Forum (April 2019), the project reportedly catalyzed 35 major infrastructure projects in South-East Asia, Central Asia, Europe, and Africa. ${ }^{83}$ With the BRI being portrayed as "a road of peace, prosperity, openness, innovation and civilization," ${ }^{4}$ China"s development-focused approach might gain further prominence in the international peacebuilding agenda. Notably, beyond infrastructure, the BRI also prescribes trade and investment liberalization, coupled with the non-conditional foreign aid that has long been practiced by China. ${ }^{85}$ Overall, as noted by an African economist Dambisa Moyo, China"s insistence on a business-oriented recipe for conflict management appears more "liberal" (i. e. capitalistic) than paternalistic Western aid that has been overwhelmed by attempts to transform postconflict states through top-down reconstruction without extensively mobilizing business actors. ${ }^{86}$

China also argues that to deliver such a development-focused strategy of conflict management/prevention, the first and foremost task lies in establishing a competent and centralized government. Having lived through the turmoil that swept through the country during the century of humiliation, the Chinese Communist leaders concluded that the state should build up its capacity to maintain social stability and set the country on a development track without distractions and abrupt course changes. ${ }^{87}$ Therefore, the Communist government took endless steps to consolidate the stability of the regime and central authority, ranging from strengthening the armed forces controlled by the Communist Party, transforming feudalist and capitalist groups, and repressing religious sects, to retaining a firm grip on the legislative and communication apparatus. ${ }^{88}$ While Western observers often argue that statist practices result in unconstrained despotism, China felt constrained by the West"s ubiquitous power and destabilizing actions - a point that corresponds with the Chinese perspective on the hegemonic international order. In a way similar to the theory of so-called "externally constrained autocracies," China asserts that non-Western countries need strong state authorities to formulate and pursue substantive social and economic policies to achieve sustained growth and decent public goods, ${ }^{89}$ as a failure to do so could easily result in (Western-fueled, if not engineered) revolutions and popular uprisings.

In such a model, ubiquitous state intervention in social life and economical construction is justifiable. ${ }^{90}$ The downside of the coin is that democracy was not conceived as a desirable end, but instead seen as an optional instrument to achieve social stability and prosperity. ${ }^{91}$ Yet this does not mean an outright Chinese rejection of democratic values. Instead, the language of democracy has been gaining ground in China since the early twentieth century, including in Communist China. However, from the start, Chinese elites emphasized the instrumental aspects of democratic values and arrangements in advancing national power, reinforcing inter-group solidarity, and maintaining regime stability, ${ }^{92}$ contrary to the Western notion of protecting individual liberty and rights from intrusive and corrupt state power. To put it differently, democracy is conceived as being "good" only if it coincides with collective pursuits and creates tangible, practical dividends. As such, public participation, or any form of democratic engagement and organization, is expected to help advance the main general goal of 
"collective welfare" - a term that essentially means social stability and economic advancement. ${ }^{93}$

This explains why China envisions a more proactive role of the host government in postconflict peacebuilding, in contrast to the highly circumscribed responsibilities assigned to the state by the West. A similar approach has been advocated by Japan that achieved miraculous postwar economic recovery under the de facto one-party rule of the Liberal Democratic Party and in absence of civil society. ${ }^{94}$ Inspired by the perceived success of the state-directed model practiced by Japan and China itself, contemporary China"s approach to peace and conflict prioritizes assistance on a government-togovernment level and leaves little room for grassroots initiatives. A strong and competent government, coupled with infrastructure-centric economic (re)construction, makes up the Chinese "peace formula" for postconflict peacebuilding.

\section{Conclusions: from historical legacies to contemporary practices}

China"s contemporary approach to peace and security is a product of continuous reflection over its historical experience of striving for national independence and sovereignty in an antagonistic international context. The notion that lasting state security is contingent on sovereign integrity, sustained socio-economic development, and inclusive international environment is rooted in the Chinese mindset across generations. This underpins the Chinese peacebuilding agenda with a consistent emphasis on non-interference, democratization of international institutions, and the peacedevelopment nexus. The developmental peace paradigm does not necessarily oppose the notion of liberal peace. As repeatedly illustrated in this article, several democratic regimes across the world, including Brazil, Indonesia, and even Japan, are sympathetic to this approach. The relevance of regime type - which is itself a construct of a Westcentric perspective - has been overrated. ${ }^{95}$ What is more relevant might be the shared experience of many non-Western countries in defending national security and social stability under hegemonic Western power and influence.

Although this article has used the West/non-West dichotomy as a heuristic analytical device, many of the norms advocated by China"s developmental peace above all, Westphalian sovereignty and non-interference - originated from the West and became internalized by China as a result of the expansion of Western liberal hegemony. Indeed, communism itself is an archetypal Western ideology with universalizing ambitions. Therefore, "the Chinese characteristics" in conflict management and peacebuilding should not be essentially "Chinese" and/or "anti-Western". ${ }^{96}$ More accurately, they manifest a divergent interpretation of roughly shared norms based on country-specific historical experiences. By the same token, when the "mainstream international society" moves towards conditional sovereignty as reflected in the notion of $\mathrm{R} 2 \mathrm{P}$, it should not be a surprise to find divergent and sometimes conflicting interpretations by non-western states, including China.

For historical reasons, China has long refrained from "promoting peace." Except for the bitter memory of the Japanese invasion under the banner of enlightenment and liberation (The Greater Asian Sphere of Co-Prosperity), ${ }^{97}$ the skepticism towards externally imposed peace has a natural affinity with the political tradition of ancient China that generally denounced any attempts to convert "the uncivilized" into "civilization." There is a deeply seated notion among the Chinese that peace and security can only be achieved through self-sustaining development linked to specific social setting and political culture of the country in question. ${ }^{99}$ Hence external actors can and should only play a supplementary role in fostering peace and prosperity - which is, in fact, consistent 
with the core vision of sustaining peace declared by the UN, as well as with the emphasis of the Japanese peacebuilders on national ownership in conflict-affected states. Overall, the principle of mutual non-interference in internal affairs has been guiding China"s engagement in conflict settings abroad, except in the years of the Maoist rule. In practice, this has translated into a value-free strategy that distinguishes the contemporary Chinese presence in conflict-affected states from the liberal West that insists on a set of self-proclaimed moral standards such as good governance, democracy, transparency, the rule of law, and respect for human rights. ${ }^{100}$ In contrast, China prioritizes "good government" over "good governance," administrative efficiency over public participation, and the right to existence and development over political and civil rights $^{101}$. Additionally, the prospect of peacebuilding, from the perspective of China, does not rest on setting in place particular political institutions, but requires building a capable government and sustainable economy that would support an endogenous process of policy learning and innovation. ${ }^{102}$

While Western academics and policy circles criticize the Chinese domination in the economic sectors of an array of fragile states, China is more concerned with the excessive Western role in political processes of postconflict peacebuilding that, from the viewpoint of China, complicates and disrupts the host country"s search for self-sustaining peace solutions. Rather than dwelling on the crude "illiberal" China versus "liberal" West divide, perhaps a more constructive way forward may be to investigate how these different visions, approaches and policy tools can be combined to tame each other"s excesses, work in parallel to harness each other"s "comparative advantages," and together build a pathway to peace that really delivers tangible improvements to nations affected by protracted conflicts. While this article does not aim to answer these questions once and for all, a historical overview provided is pertinent to advancing our understanding of these important theoretical and empirical issues. Specifically, conclusions drawn in this article provide a starting point for an ongoing project conducted by the Centre on Conflict, Development and Peacebuilding in Geneva that seeks to critically compare and contrast the normative and practical underpinnings of non-Western approaches to peacebuilding.

\section{ENDNOTES}

\footnotetext{
1 China peacekeeping exhibition launched at UN headquarters // Xinhua Net. 02.02.2019. URL: http://www.xinhuanet.com/english/2019-02/12/c_137815380.htm.
}

2 How We Are Funded. UN Department of Peace Operations official web-site. URL: https://undocs.org/ A/73/350/Add.1, accessed 02.01.2020.

3 Ibid.

4 Wang 2018a; He 2017.

5 Zhao L. 2011.

${ }^{6}$ Butler and Wheeler 2012.

7 Kuo 2015

${ }^{8}$ Gwaza 2015.

9 Interview with He Yin in Beijing, June 2019. 
10 Wang 2018.

11 Xi 2012

12 By "the West", this article refers to Western Europe, Australasia, and North America - regions comprised of those states that dominate norm-making in international institutions. Chinese notion of "the West", however, originated from the ideological rivalry of the Cold War times. China"s present official discourse about "the West" centers around capitalist, democratic, developed countries associated with Christianity, making it an ideological, cultural and economic category at once. This explains why, in this article, countries such as Brazil, Argentina and Japan are treated as non-Western. See, for example, Wang Q. Fundamental differences between China and Western countries determine that China cannot follow the Western path // Qiushi Net. 22.01.2017. URL: http://www.qstheory.cn/dukan/ hqwg/2017-01/22/c_1120360920.htm.

13 Beeson 2009; Wei 2020; Kuo 2015; Kuo 2012; He 2017; Zhao L. 2010; Wu 2001.

14 A notion that security can only be sustained through cooperation and common development. Ghiasy and Zhou 2017.

15 Kuo 2015; Wang 2018; Alden and Barber 2018; Benabdallah 2016; Zhao L. 2011; Curtis 2013.

16 Beeson 2009; Dreher and Fuchs 2015.

17 Zhao L. 2011.

18 Kuo 2015; Kuo 2012; He 2017; Wei 2020; Beeson 2009.

19 Krause and Jütersonke 2005.

20 Ibid.

21 Risse and Babayan 2015; Dreher and Fuchs 2015.

22 See: Kobayashi 2020 in this issue.

23 Kondoh 2015; Abdenur 2016; Stuenkel 2013; Ichihara 2019.

${ }^{24}$ He 2017; Zhang F. 2010.

25 Zhao T. 2011, Zhang F. 2010.

${ }^{26}$ Kelly 2011.

27 Zhao T. 2011.

28 Kang 2012.

29 Kang finds that between the $14^{\text {th }}$ and $19^{\text {th }}$ century, there were only two wars between China and its Confucian neighbors. See: Kang 2008.

30 He 2017, Kelly 2011.

31 Graff 1997; Feng Z. 2009; Bell 2009; Feng H. 2007; Johnston 1993.

32 Kelly 2011.

33 Ibid.: Xiang 2020. 
${ }^{34}$ China"s White Paper on Peaceful Development. Information Office of the State Council, The People"s Republic of China. - Beijing, September 2011.

35 Xi 2014.

${ }^{36}$ Bell 2009.

37 Zhang Yo. 1991.

${ }^{38}$ Xiang 2020, p. 4.

39 Zhang Yo. and Buzan 2012.

40 Jiang Zemin's Speech at the Meeting Celebrating the 80th Anniversary of the Founding of the Communist Party of China. 1 July 2001. Permanent Mission of PRC to the UN Office in Geneva. Official web-site. URL: http://www.china-un.ch/eng/zgbd/smwx/t85789.htm.

${ }^{41}$ Zhang Yo. 1991.

${ }^{42}$ Benabdallah 2016.

${ }^{43}$ The term initially referred to the capitalist USA and was then extended to include the USSR after the Sino-Soviet split over ideological and sovereignty issues.

${ }^{44}$ Garver 1979.

45 Deng 1974.

46 Alden and Alves 2008.

47 Zhang F. 2011.

${ }^{48}$ Selected Works of Mao Zedong"s Thoughts on Diplomacy (Mao Zedong Waijiao Wenxuan). Research Office of the CCP Central Committee, 1994, p. 53.

${ }^{49}$ Xi 2015.

50 Yang 2010.

51 Bell 2009, Li 2006.

52 He 2017.

53 The cultural heritage of "Harmony" in President Xi Jinping's diplomacy: China does not have warlike cultural genes // CPC News. 15.07.2015. URL: http://cpc.people.com.cn/xuexi/n/2015/0715/ c385474-27309679.html.

${ }^{54}$ Reilly and Gill 2000, Leifer 1996, Hughes 2005.

55 Formulation of Foreign Policy of New China on the Eve of its Birth. Ministry of Foreign Affairs of PRC. Official web-site. http://www.fmprc.gov.cn/mfa_eng/ziliao_665539/3602_665543/3604_665547/ t18057.shtml.

${ }^{56}$ Zhang F. 2011.

57 Li 2010. 
58 Conclusion of the "Sino-Soviet Treaty of Friendship, Alliance and Mutual Assistance". Ministry of Foreign Affairs of People's Republic of China. Official web-site. URL: http://www.fmprc.gov.cn/mfa_ eng/ziliao_665539/3602_665543/3604_665547/t18011.shtml.

${ }^{59}$ Remarks by Mao Zedong concerning the Soviet request on establishing a special long-wave radio station in China. 7 June 1958 // Digital Archive, Wilson Center. URL: https://digitalarchive. wilsoncenter.org/document/117032.

${ }^{60}$ Li 2010.

${ }^{61}$ Carlson 2003.

62 Zhang Yu. 2016.

${ }^{63}$ Kane 2001, p. 48.

64 Acharya 2014.

${ }^{65}$ Zhao L. 2011.

${ }^{66}$ Ibid.

${ }^{67}$ Stuenkel 2014.

${ }^{68}$ Menegazzi 2012.

${ }^{69}$ Vickers 2009.

70 lbid.

${ }^{71}$ Naím 2007, Halper 2010.

72 Brand, McEwen-Fial and Muno 2015.

${ }^{73}$ Bader 2015.

74 Perry 2008.

${ }^{75}$ Kane 2001

${ }^{76}$ Perry 2008.

${ }^{77}$ Liu and Tian 2009.

78 Schwartz 1968.

${ }^{79}$ Wei 2020.

${ }^{80}$ Reporter revisits Tanzania-Zambia railway (Jizhe Chongzou Woguo Yuanjian De Tanzan Tielu) // Xinhua Net. 04.10.2020. URL: http://news.sina.com.cn/c/sd/2010-08-04/170620826263.shtml.

${ }^{81}$ Robinson and Shambaugh 1996, p. 287.

${ }^{82}$ Ministry of Foreign Affairs of China Brief. 07.11.2000. URL: http://www.fmprc.gov.cn/web/ziliao_ 674904/wjs_674919/2159_674923/t9001.shtml.

83 Joint Communique of the Leaders" Roundtable of the 2nd Belt and Road Forum for International Cooperation, 2019. China"s Ministry of Foreign Affairs. Official web-site. URL: http://www.fmprc.gov. cn/mfa_eng/zxxx_662805/t1658766.shtml. 
84 Xi 2017

85 Dreher and Fuchs 2015.

${ }^{86}$ Moyo and Ferguson 2010.

87 French H. Letter from China: what if Beijing is right? // The New York Times. 2 November 2007.

88 Zhao S. 2010

89 Beeson 2009.

90 Ibid.

91 Zhao L. 2010.

92 Nathan 1986, Zhao S. 2010.

93 Perry 2008.

94 Kobayashi 2020.

95 Menegazzi 2012.

96 Zhao L. 2011, p. 352.

97 Mimura 2011.

98 Zhang F. 2011, He 2017, Zhang Yo. and Buzan 2012.

99 Zhao T. 2011.

100 Zhao S. 2010.

101 While the important issues of the efficacy and implications of Chinese approach to conflict management and peacebuilding deserve further inquiry, this article primarily aims to investigate the historical origin and philosophical foundation of this emerging approach and does not engage with normative issues (e. g. whether the developmental peace is "better" than the liberal peace or vice versa). Meanwhile, the notion of "successful peacebuilding" per se remains vague, obviously depending on how "success" is defined. In fact, it is hard to find "successful" cases of liberal peace operations since the end of the Cold War, if "success" is measured in terms of the conformity of host states with prevailing liberal norms. As Kazushige Kobayashi points out in his article in this issue, Western-backed liberal peacebuilding efforts in Kosovo, Bosnia and Herzegovina, Afghanistan, Iraq, Libya, Egypt, Tunisia, Lebanon, and across Africa and the Middle East typically ended up with fragile quasi-states and/or divided societies plagued with kleptocracy (Kazushige 2020), in which "domestic governance is weak, armed violence remains high, and respect for human rights and the rule of law is questionable" (Krause and Oliver 2005). It is in this context that the relative attractiveness of the development-focused approach of China has been reinforced, especially in Africa (Moyo 2010). For empirical investigation of Chinese engagement in conflict-affected settings and the interactions with the liberal peace agenda, see the forthcoming Country Brief Report to be published by Centre on Conflict, Development and Peacebuilding, Graduate Institute of International and Development Studies, Geneva.

102 He 2017. 


\section{BIBLIOGRAPHY}

1. Abdenur A. E. Rising powers and international security: the BRICS and the Syrian conflict // Rising Powers Quarterly. V.1. No. 1. 2016. P. 109-133.

2. Acharya A. Who are the norm makers? The Asian-African Conference in Bandung and the evolution of norms // Global Governance. V. 20. No. 3. 2014. P. 405-417.

DOI: $10.1163 / 19426720-02003006$.

3. Alden C., Alves C. History \& identity in the construction of China"s Africa policy // Review of African Political Economy. V. 35. No. 115. 2008. P. 43-58. DOI: 10.1080/03056240802011436.

4. Alden C., Barber L. Introduction: seeking security: China"s expanding involvement in security cooperation in Africa // China and Africa: Building Peace and Security Cooperation on the Continent. Ed. by C.Alden, A.Alao, Zh.Chun and L.Barber. Cham: Springer International Publishing, 2018. P. 1-10. DOI: 10.1007/978-3-319-52893-9_1.

5. Bader J. China, autocratic patron? An empirical investigation of China as a factor in autocratic survival // International Studies Quarterly. V. 59. 2015. P. 23-33.

DOI: 10.1111/isqu.12148.

6. Beeson M. Developmental states in East Asia: a comparison of the Japanese and Chinese experiences // Asian Perspective. V. 33. No. 2. 2009. P. 5-39.

DOI: 10.1353/apr.2009.0016.

7. Bell D. A. War, peace, and China"s soft power: a Confucian approach // Diogenes. V. 56. No. 1. 2009. P. 26-40. DOI: 10.1177/0392192109102153.

8. Benabdallah L. China"s peace and security strategies in Africa: building capacity is building peace? // African Studies Quarterly. V. 16. No. 3. 2016. P. 17-34.

9. Brand A., McEwen-Fial S., Muno W. An „authoritarian nexus"? China"s alleged special relationship with autocratic states in Latin America // European Review of Latin American and Caribbean Studies / Revista Europea de Estudios Latinoamericanos y Del Caribe. No. 99. 2015. P. 7-28.

10. Butler D. M., Wheeler T. China and Conflict-affected States. - London: Saferworld, 2012.

11. Carlson A. Constructing the dragon"s scales: China"s approach to territorial sovereignty and border relations in the 1980s and 1990s // Journal of Contemporary China. V. 12. No. 37. 2003. P. 677-698. DOI: 10.1080/1067056032000117704.

12. China peacekeeping exhibition launched at UN headquarters // Xinhua Net. 02.02.2019. URL: http://www.xinhuanet.com/english/2019-02/12/c_137815380.htm.

13. China"s White Paper on Peaceful Development. Information Office of the State Council, The People"s Republic of China. - Beijing, September 2011. URL: http://english.www. gov.cn/archive/white_paper/2014/09/09/content_281474986284646.htm.

14. Conclusion of the "Sino-Soviet Treaty of Friendship, Alliance and Mutual Assistance". Ministry of Foreign Affairs of People's Republic of China. Official web-site.

URL: http://www.fmprc.gov.cn/mfa_eng/ziliao_665539/3602_665543/3604_665547/ t18011.shtml.

15. The cultural heritage of "Harmony" in President Xi Jinping's diplomacy: China does not have war-like cultural genes // CPC News. 15.07.2015. URL: http://cpc.people.com.cn/ xuexi/n/2015/0715/ c385474-27309679.html.

16. Curtis D. China and the insecurity of development in the Democratic Republic of the Congo (DRC) // International Peacekeeping. V. 20. No. 5. 2013. P. 551-569.

DOI: $10.1080 / 13533312.2013 .853950$.

17. Deng X. Zai Lianda Diliu Jie Tebie Huiyi Shang De Jianghua (Speech at the sixth special session of the General Assembly of the United Nations). New York, April 1974.

URL: http://www.people.com.cn/GB/shizheng/252/6688/6715/20011023/588430.html.

18. Dreher A., Fuchs A. Rogue aid? An empirical analysis of China"s aid allocation // Canadian Journal of Economics/Revue canadienne d"économique. V. 48. No. 3. 2015. P. 988-1023. DOI: 10.1111/caje.12166. 
19. Feng H. Chinese Strategic Culture and Foreign Policy Decision-Making: Confucianism, Leadership and War. - London: Routledge, 2007.

20. Feng Z. Rethinking the "tribute system": broadening the conceptual horizon of historical East Asian politics // The Chinese Journal of International Politics. V. 2. No. 4. 2009. P. 545-574. DOI: 10.1093/cjip/pop010.

21. Formulation of Foreign Policy of New China on the Eve of its Birth. Ministry of Foreign Affairs of PRC. Official web-site. URL: http://www.fmprc.gov.cn/mfa_eng/ziliao_665539/ 3602_665543/3604_665547/ t18057.shtml.

22. French $\mathrm{H}$. Letter from China: what if Beijing is right? // The New York Times. 2 November 2007.

23. Garver J. W. Book review: Revolutionary Diplomacy: Chinese Foreign Policy and the United Front Doctrine // The China Quarterly. V. 79. 1979. P. 630-633. DOI: $10.1017 / S 0305741000038443$.

24. Ghiasy R., Zhou J. The Silk Road Economic Belt: Considering Security Implications and EU-China Cooperation Prospects. - Stockholm: Stockholm International Peace Research Institute, 2017.

25. Graff D. A. Book review: Review of Cultural Realism: Strategic Culture and Grand Strategy in Chinese History by Alastair lain Johnston // China Review International. V. 4. No. 2. 1997. P. 450-453.

26. Gwaza P. A. Developmental Peace: Understanding China"s Policy towards Africa in Peace and Security. - Rochester, NY: Social Science Research Network, 2015. DOI: $10.2139 /$ ssrn.2544850.

27. Halper S. The Beijing Consensus: How China"s Authoritarian Model Will Dominate the Twenty-First Century. - New York: ReadHowYouWant.com, 2010.

28. He Y. Fazhan Heping: Lianheguo Jianshe Heping de Zhongguo Fangan (Developmental peace: Chinese approach to UN peacekeeping and peacebuilding) // Guoji Zhengzhi Yanjiu (The Journal of International Studies). V. 38. No. 4. 2017. P. 10-32.

29. How We Are Funded. UN Department of Peace Operations official web-site. URL: https://undocs.org/ A/73/350/Add.1, accessed 02.01.2020.

30. Hughes C. R. Nationalism and multilateralism in Chinese foreign policy: implications for Southeast Asia // The Pacific Review. V. 18. No. 1. 2005. P. 119-135. DOI: 10.1080/09512740500047231.

31. Ichihara M. International power structure and strategic motivations: democracy support from Japan and Indonesia. Japan International Cooperation Agency (JICA) Ogata Sadako Research Institute for Peace and Development Working Paper. August 2019. URL: http://www.jica.go.jp/jicari/publication/workingpaper/wp_194.html.

32. Jiang Zemin's Speech at the Meeting Celebrating the 80th Anniversary of the Founding of the Communist Party of China. 1 July 2001. Permanent Mission of PRC to the UN Office in Geneva. Official web-site. URL: http://www.china-un.ch/eng/zgbd/smwx/ t85789.htm.

33. Jizhe Chongzou Woguo Yuanjian De Tanzan Tielu (Reporter revisits Tanzania-Zambia railway) // Xinhua Net. 04.10.2020. URL: http://news.sina.com.cn/c/sd/2010-0804/170620826263.shtml.

34. Johnston A. I. An Inquiry into Strategic Culture: Chinese Strategic Thought, the Parabellum Paradigm, and Grand Strategic Choice in Ming China. - Ann Arbor: University of Michigan,1993.

35. Joint Communique of the Leaders" Roundtable of the 2nd Belt and Road Forum for International Cooperation, 2019. China"s Ministry of Foreign Affairs. Official web-site. URL: http://www.fmprc.gov.cn/mfa_eng/zxxx_662805/t1658766.shtml.

36. Kane T. China"s foundations: guiding principles of Chinese foreign policy // Comparative Strategy. V. 20. No. 1. 2001. P. 45-55. DOI: 10.1080/01495930150501106.

37. Kelly R. E. A "Confucian long peace" in pre-Western East Asia? // European Journal of International Relations. V. 18. No. 3. 2011. P. 407-430.

DOI: $10.1177 / 1354066111409771$. 
38. Kobayashi K. Japanese pathways to peacebuilding: from historical legacies to contemporary practices // Pathways to Peace and Security [Puti k miru i bezopasnosti]. No. 1(58). 2020. P. 9-25.

39. Kondoh $\mathrm{H}$. Convergence of aid models in emerging donors? Learning processes, norms and identities, and recipients. JICA Ogata Sadako Research Institute for Peace and Development Working Paper. July 2015. URL: https://www.jica.go.jp/jicari/publication/ workingpaper/post_16.html.

40. Krause K., Jütersonke O. Peace, security and development in post-conflict environments. Security Dialogue. V. 36. No. 4. 2005. P. 447-462. DOI: 10.1177/0967010605060449.

41. Kuo S. Beijing"s understanding of African security: context and limitations // African Security. V. 5. No. 1. 2012. P. 24-43. DOI: 10.1080/19392206.2012.653306.

42. Kuo S. Chinese peace? An emergent norm in African peace operations // China Quarterly of International Strategic Studies. V. 1. No. 15. P. 155-181.

DOI: 10.1142/S2377740015500086.

42. Leifer M. The ASEAN Regional Forum. - Oxford: Routledge, 1996.

43. Li H.-Yu. China Learns from the Soviet Union, 1949-Present. - Lanham, MD: Rowman \& Littlefield, 2010.

44. Liu H., Keqin T. Mao Zedong Weishenme Yao Tichu Ganchao Zhanlve (Why did Mao Zedong propose a Catch-up Strategy) // CPC News. December 2009.

URL: http://dangshi.people.com.cn/GB/144956/10571639.html.

45. Mao Zedong Waijiao Wenxuan [Selected Works of Mao Zedong"s Thoughts on Diplomacy]. - Beijing: Research Office of the CCP Central Committee, 1994.

46. Menegazzi S. China Reinterprets the Liberal Peace. - Rome: Istituto affari internazionali, 2012.

47. Mimura J. Japan"s new order and Greater East Asia Co-Prosperity Sphere: planning for empire // The Asia-Pacific Journal. V. 9. No. 49. 2011. P. 1-12.

48. Ministry of Foreign Affairs of China Brief. 07.11.2000. URL: http://www.fmprc.gov.cn/ web/ziliao_674904/wjs_674919/2159_674923/t9001.shtml.

49. Moyo D., Ferguson N. Dead Aid: Why Aid Is Not Working and How There Is a Better Way for Africa. - New York: Farrar, Straus and Giroux, 2010.

50. Naím M. Rogue aid // Foreign Policy. 15 October 2009. URL: https://foreignpolicy.com/ 2009/10/15/rogue-aid/.

51. Nathan A. J. Chinese Democracy. - Berkeley: University of California Press, 1986.

52. Perry E. J. Chinese conceptions of "rights": from Mencius to Mao - and now // Perspectives on Politics. V. 6. No. 1. 2008. P. 37-50.

DOI: $10.1017 / S 1537592708080055$.

53. Reilly J., Gill B. Sovereignty, intervention and peacekeeping: the view from Beijing // Survival. V. 42. No. 3. 2000. P. 41-60. DOI: 10.1093/survival/42.3.41.

54. Remarks by Mao Zedong concerning the Soviet request on establishing a special longwave radio station in China. 7 June 1958 // Digital Archive, Wilson Center.

URL: https://digitalarchive. wilsoncenter.org/document/117032.

55. Risse T., Babayan N. Democracy promotion and the challenges of illiberal regional powers: introduction to the special issue // Democratization. V. 22. No. 3. 2015. P. 381399. DOI: 10.1080/13510347.2014.997716.

56. Robinson T., Shambaugh D. Chinese Foreign Policy: Theory and Practice. - Oxford: Oxford University Press, 1996.

57. Schwartz B. I. Communism and China: Ideology in Flux. - Cambridge, Mass.: Harvard University Press, 1968.

58. Stuenkel O. Rising powers and the future of democracy promotion: the case of Brazil and India // Third World Quarterly. V. 34. No. 2. 2013. P. 339-355.

DOI: 10.1080/01436597.2013.775789.

59. Stuenkel O. The BRICS and the future of R2P: was Syria or Libya the exception? // Global Responsibility to Protect. V. 6. 2014. P. 3-28. DOI: 10.1163/1875984X-00601002. 
60. Vickers E. Selling "Socialism with Chinese characteristics": "thought and politics" and the legitimization of China"s developmental strategy // International Journal of Educational Development. V. 29. No. 5. 2009. P. 523-531. DOI: 10.1016/j.jjedudev.2009.04.012.

61. Wang Q. Fundamental differences between China and Western countries determine that China cannot follow the Western path // Qiushi Net. 22.01.2017.

URL: http://www.qstheory.cn/dukan/hqwg/2017-01/22/c_1120360920.htm.

62. Wang X. Developmental peace: understanding China"s Africa policy in peace and security // China and Africa: Building Peace and Security Cooperation on the Continent. Ed. by C.Alden, A.Alao, Z.Chun, L.Barber. - Cham: Springer International Publishing, 2018. P. 67-82. DOI: 10.1007/978-3-319-52893-9 4.

63. Wei L. Developmental peace in East Asia and its implications for the Indo-Pacific // International Affairs. V. 96. No. 1. 2020. P. 189-209. DOI: 10.1093/ia/iiz230.

64. Wu B. The Chinese security concept and its historical evolution // Journal of Contemporary China. V. 10. No. 27. 2001. P. 275-283. DOI: 10.1080/10670560124748.

65. Xi J. Address at the commemoration of the 70th anniversary of the victory of the Chinese People"s War of Resistance against Japanese aggression and the World anti-Fascist war. Beijing, September 2015. URL: http://www.fmprc.gov.cn/mfa_eng/topics_665678/ jnkzsl70zn/t1293415.shtml.

66. Xi J. Open Up New Horizons for China-Mongolia Relations Through Mutual Assistance. Speech at the State Great Khural of Mongolia. August 2014.

URL: http://www.china.org.cn/chinese/2014-08/28/content 33365549.htm.

67. Xi J. Work together to build the Silk Road Economic Belt and the 21st century Maritime Silk Road. Beijing: The Opening Ceremony of The Belt and Road Forum for International Cooperation. May 2017. URL: http://www.catl.org.cn/201705/15/content_41501866.htm.

68. Xi J. Xieshou Hezuo, Gongtong Weihu Shijie Heping Yu Anquan (Work together to build world peace and security). - Beijing: The World Peace Forum, July 2012.

URL: http://www.gov.cn/ldhd/2012-07/07/content_2178506.htm.

69. Xiang L. The Quest for Legitimacy in Chinese Politics: A New Interpretation. - London; New York: Routledge, 2020.

70. Yang K. Revolutionary diplomacy thought and practice of new China // Historiography Monthly (Shixue Yuekan). V. 2. 2010. P. 62-74.

71. Zhang F. The rise of Chinese exceptionalism in international relations // European Journal of International Relations. V. 19. No. 2. 2011. DOI: 10.1177/1354066111421038.

72. Zhang F. The Tianxia system: world order in a Chinese utopia // Global Asia. Special issue. January 2010. URL: http://www.chinaheritagequarterly.org/tienhsia.php?search term $=021$ utopia.inc\&issue $=021$.

73. Zhang Yo. China"s entry into international society: beyond the standard of "civilization" // Review of International Studies. V. 17. No. 1. 1991. P. 3-16.

DOI: 10.1017/S026021050011229X.

74. Zhang Yo., Buzan B. The tributary system as international society in theory and practice // The Chinese Journal of International Politics. V. 5. No. 1. 2012. P. 3-36.

DOI: $10.1093 / \mathrm{cjip} /$ pos001.

75. Zhang Yu. Zhongguo Ruhe Canyu Quanqiu Zhili He Guize Boyi (How does China participate in global governance and rule-making?) // Shijie Zhishi (World Knowledge). V. 15. 2016.

76. Zhao L. Two pillars of China"s global peace engagement strategy: UN peacekeeping and international peacebuilding // International Peacekeeping. V. 18. No. 3. 2011. P. 344362.

77. Zhao S. The China model: can it replace the Western model of modernization? // Journal of Contemporary China. V. 19. No. 65. 2010. P. 419-436.

DOI: 10.1080/10670561003666061.

78. Zhao T. The Tianxia System: An Introduction to the Philosophy of World Institution. Beijing: China Renmin University Press, 2011. 